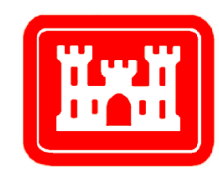

US Army Corps of Engineers ${ }_{\circledast}$

\section{AIS Data Case Study: St. Louis Area Commercial Vessel Fleeting Activity and Potential River Training Structures}

PURPOSE: The US Army Corps of Engineers (USACE), St. Louis District (MVS), needed to examine commercial river traffic patterns before designing new river training structures to reduce maintenance dredging costs in the St. Louis Harbor area of the Middle Mississippi River (MMR). The MMR is considered to be that portion of the Mississippi River from the confluence of the Missouri River down to the Ohio River, and the Upper Mississippi River (UMR) is everything north of the Missouri River. MVS analyzed historic Automatic Identification System (AIS) data, which provide georeferenced and timestamped position reports for commercial vessels, to reveal river use patterns. The Mississippi River within the MVS area of responsibility is heavily trafficked by the shipping industry and includes numerous loading facilities and fleeting areas that are outside of the main navigation channel. This work identified previously unknown fleeting areas in locations that were being considered for siting of river training structures. These areas were then removed from potential construction consideration, thus avoiding conflict with shipping industry river use.

INTRODUCTION: The waterways within MVS handle an average of over 100 million tons of commodities per year (USACE-WCSC 2019). The MVS includes the MMR and parts of the Upper Mississippi River, the Illinois River, and the Missouri River. Marine transportation infrastructure in the area includes public and private port facilities and 15 separate barge-transfer facilities that can handle up to 150 barges per day (St. Louis Regional Freightway 2019). MVS conducts regular dredging to maintain a navigation channel on the Mississippi River that is at least 9 feet ( $\mathrm{ft}$ ) deep and $300 \mathrm{ft}$ wide (with additional width in bends). Table 1 shows that the volume of material removed via maintenance dredging in the St. Louis Harbor area from 2007 to 2017 has increased over the past decade relative to the overall MMR area - for which dredging needs have been relatively stable except for 2012. This increasing need for maintenance dredging in the St. Louis Harbor led to suggestions for the construction of additional river training structures to control sediment movement in the river and thus reduce the amount of required dredging.

However, before designing any river training structures, the MVS needed to understand the current spatial and temporal patterns of river use. AIS transceiver units aboard ships broadcast data that document these vessels' timestamped and georeferenced positions. The primary purpose of these broadcasts is collision avoidance. The broadcasts are collected by shoreside towers and ultimately archived by the US Coast Guard (USCG) as part of the Nationwide Automatic Identification System (NAIS) program (USCG 2018). Archived AIS data have been used for different aspects of waterway performance monitoring in multiple locations around the United States (DiJoseph et al. 2019; Mitchell and Scully 2014; Scully and Mitchell 2015; Young and Scully 2018); however, this was the first application of AIS data analysis within MVS for the purpose of informing consideration of new river training structures. 


\begin{tabular}{|c|c|c|c|}
\hline $\begin{array}{l}\text { Calendar } \\
\text { Year }\end{array}$ & $\begin{array}{c}\text { St. Louis Harbor Dredge Volume } \\
\text { Quantity } \\
\text { (cubic yards) }\end{array}$ & $\begin{array}{l}\text { MMR Dredge Volume Quantity } \\
\text { (cubic yards) }\end{array}$ & $\begin{array}{l}\text { Ratio of St. Louis Harbor } \\
\text { Dredge Material Volume to } \\
\text { MMR Dredge Material Volume }\end{array}$ \\
\hline 2007 & 82,900 & $3,709,400$ & 0.02 \\
\hline 2008 & 248,000 & $3,090,000$ & 0.08 \\
\hline 2009 & 392,400 & $2,312,500$ & 0.17 \\
\hline 2010 & 159,600 & $1,672,600$ & 0.10 \\
\hline 2011 & 666,088 & $2,016,116$ & 0.33 \\
\hline 2012 & $1,516,626$ & $9,220,215$ & 0.16 \\
\hline 2013 & $1,102,019$ & $5,727,894$ & 0.19 \\
\hline 2014 & $1,115,975$ & $1,812,702$ & 0.62 \\
\hline 2015 & $1,154,238$ & $1,721,068$ & 0.67 \\
\hline 2016 & $1,297,153$ & $2,194,457$ & 0.59 \\
\hline 2017 & $1,466,558$ & $3,050,656$ & 0.48 \\
\hline Average & $836,505.18$ & $3,320,691.64$ & 0.31 \\
\hline
\end{tabular}

METHOD: AIS data within the MMR between River Mile 157 and River Mile 184 were collected by the USCG in the years 2015, 2016, and 2017, and obtained by the MVS in 15-second (sec) intervals in March 2018. These data were provided in comma-separated value (CSV) format, which is accessible to most spreadsheet software packages. Custom Microsoft PowerShell scripts were written to perform the initial data cleaning and to separate the records into smaller CSV files that could be read into ArcMap version 10.4.1 (ESRI 2019) for geospatial analysis. Within ArcMap, a custom toolset was created to perform batch processing to transform CSV files into shapefiles, with each shapefile containing 1 month of AIS data for a designated portion of river. An example of approximately 215,000 georeferenced AIS vessel position records from February 2015 is shown in Figure 1, with each AIS position record shown as a black dot.

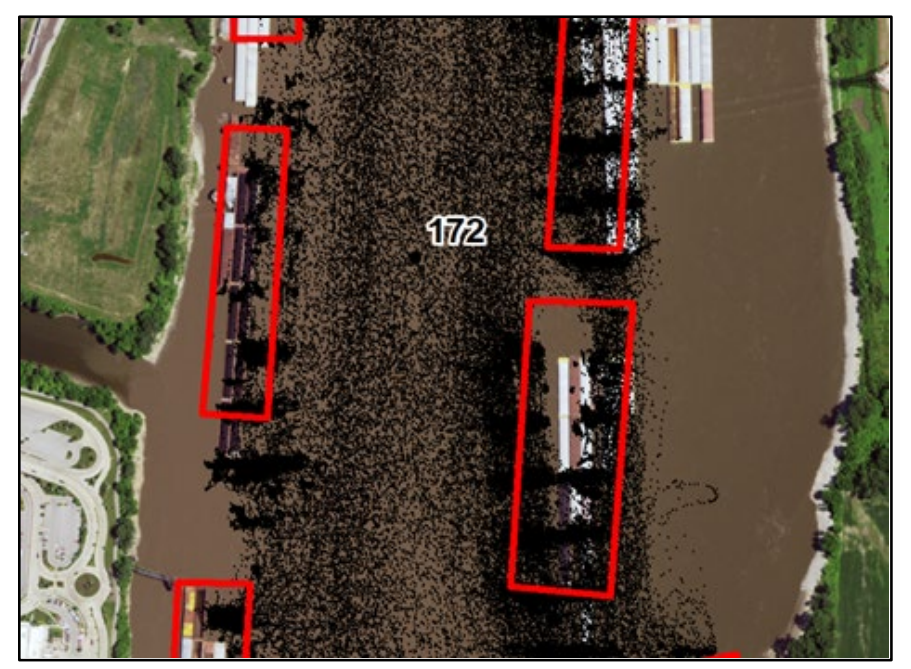

Figure 1. AIS vessel position records (black dots) near River Mile 172 in February 2015. Red boxes show previously known fleeting areas. 
The overlap between thousands of position records obscured the true spatial variation in intensity of river use. To improve the visual representation of AIS data, a nearest-neighbor clustering routine was performed with a $5 \mathrm{ft}$ radius limit. This process identifies all individual position records within a $5 \mathrm{ft}$ radius within a day and consolidates those into a single representative point. The cluster mapping function is available within ArcMap. The results of the cluster mapping allowed for clearer visual representation of hot spots of heavy usage; an example of the resulting product is shown in Figure 2.

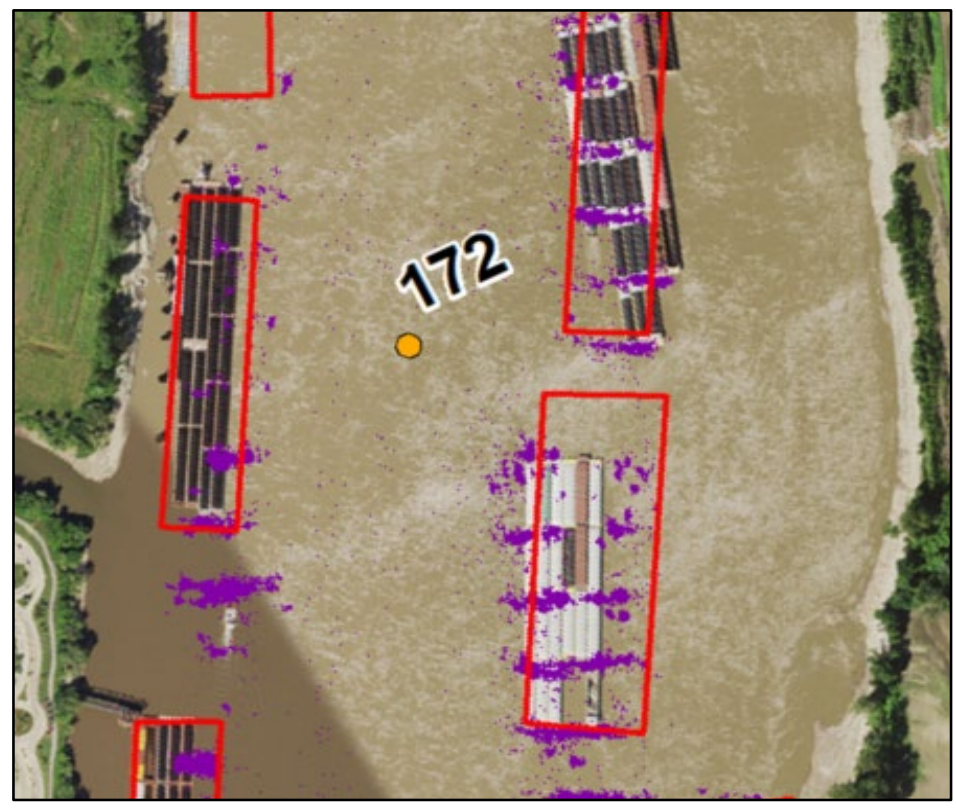

Figure 2. Cluster map of AIS vessel position records (purple dots) near River Mile 172 in February 2015. Red boxes show previously known fleeting areas.

This process was repeated for each month of data for the MMR, divided into the following River Miles segments:

- $184.0-181.0$

- $181.0-178.0$

- $178.0-175.0$

- $175.0-172.0$

- $172.0-169.0$

- $169.0-166.0$

- $166.0-163.0$

- $163.0-160.0$

- $160.0-157.0$.

RESULTS: The results of this analysis revealed four insights about commercial vessel traffic on the MMR between River Mile 157.0 and River Mile 184.0:

- vessel fleeting/staging activities occur outside of previously known areas

- existing known fleeting areas are not all equally utilized spatially or temporally

- use of some fleeting/staging areas is seasonal

- use of secondary navigation channels is greater than expected. 
An example of the significant vessel fleeting/staging activities occurring outside of previously known areas is shown in Figure 3. Figure 4 shows less utilization than expected for a group of previously known fleeting areas (indicated with red arrows), with no historical vessel position record clusters identified during the 3-year study period.

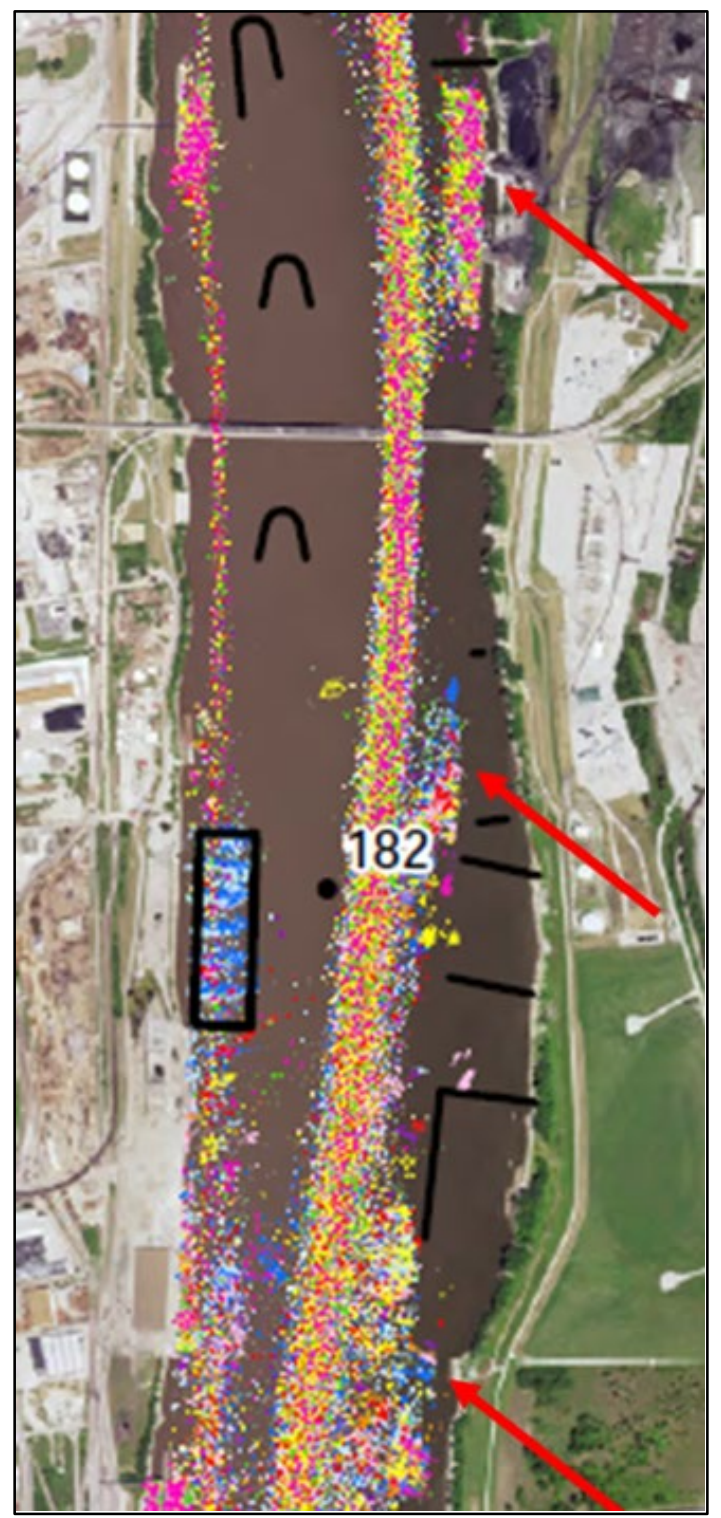

Figure 3. Monthly AIS vessel position reports (multi-color dots) near River Mile 182. Black box indicates previously known fleeting area, black lines and chevrons represent existing river training structure. Red arrows point to areas of previously unknown fleeting activity outside of known areas.

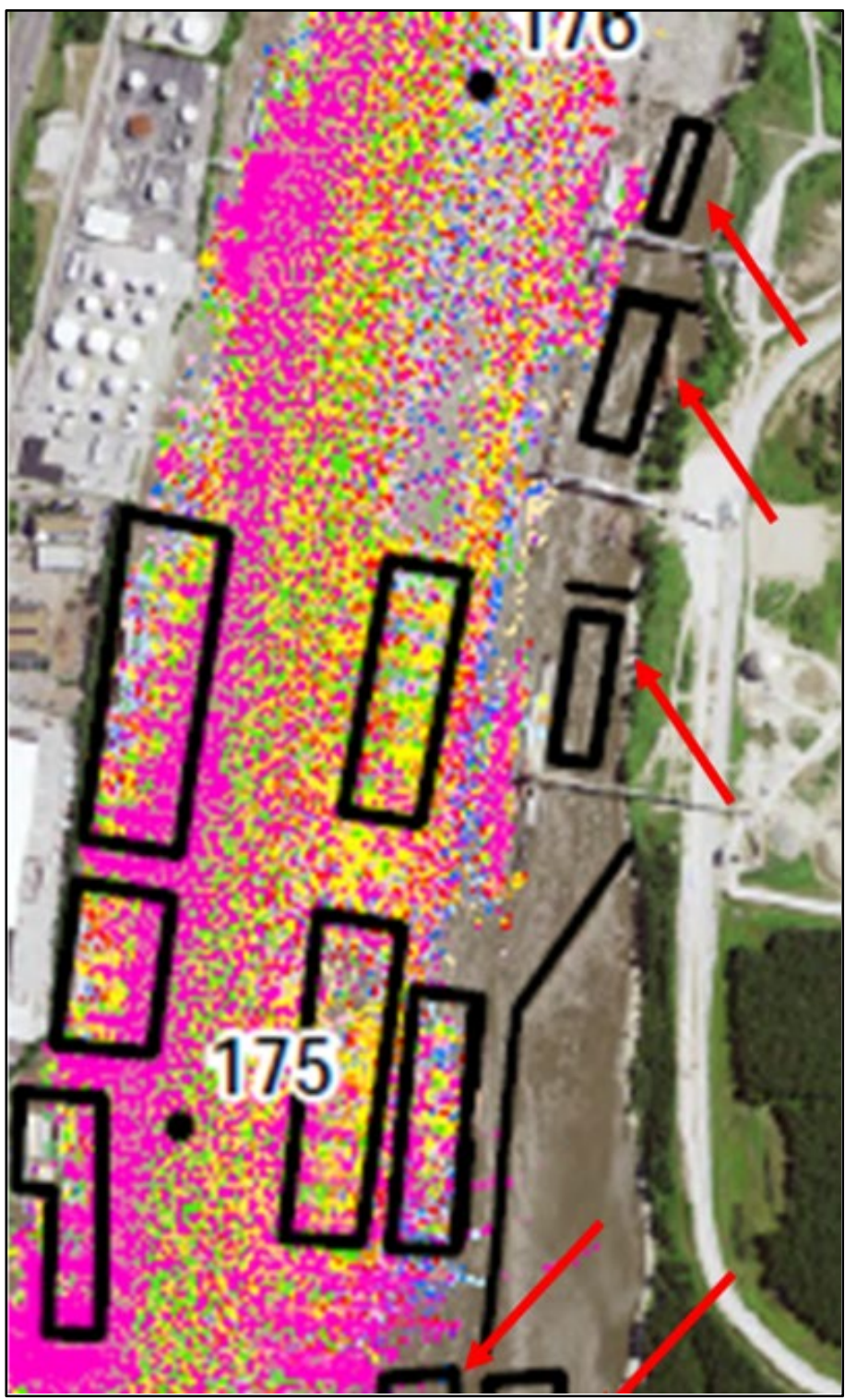

Figure 4. Monthly AIS vessel position reports (multi-color dots) near River Mile 175. Black boxes represent previously known fleeting areas. Results demonstrate a shift in utilization away from certain previously known fleeting areas (indicated by red arrows). 
Figure 5 shows the highly seasonal use of a group of previously known fleeting areas near River Mile 174; the red and orange dots represent only 2 months of the year. Figure 6 shows the use of three distinct paths, a primary navigation channel and two secondary channels, by vessels transiting an area of the MMR at St. Louis with multiple bridges in close proximity.

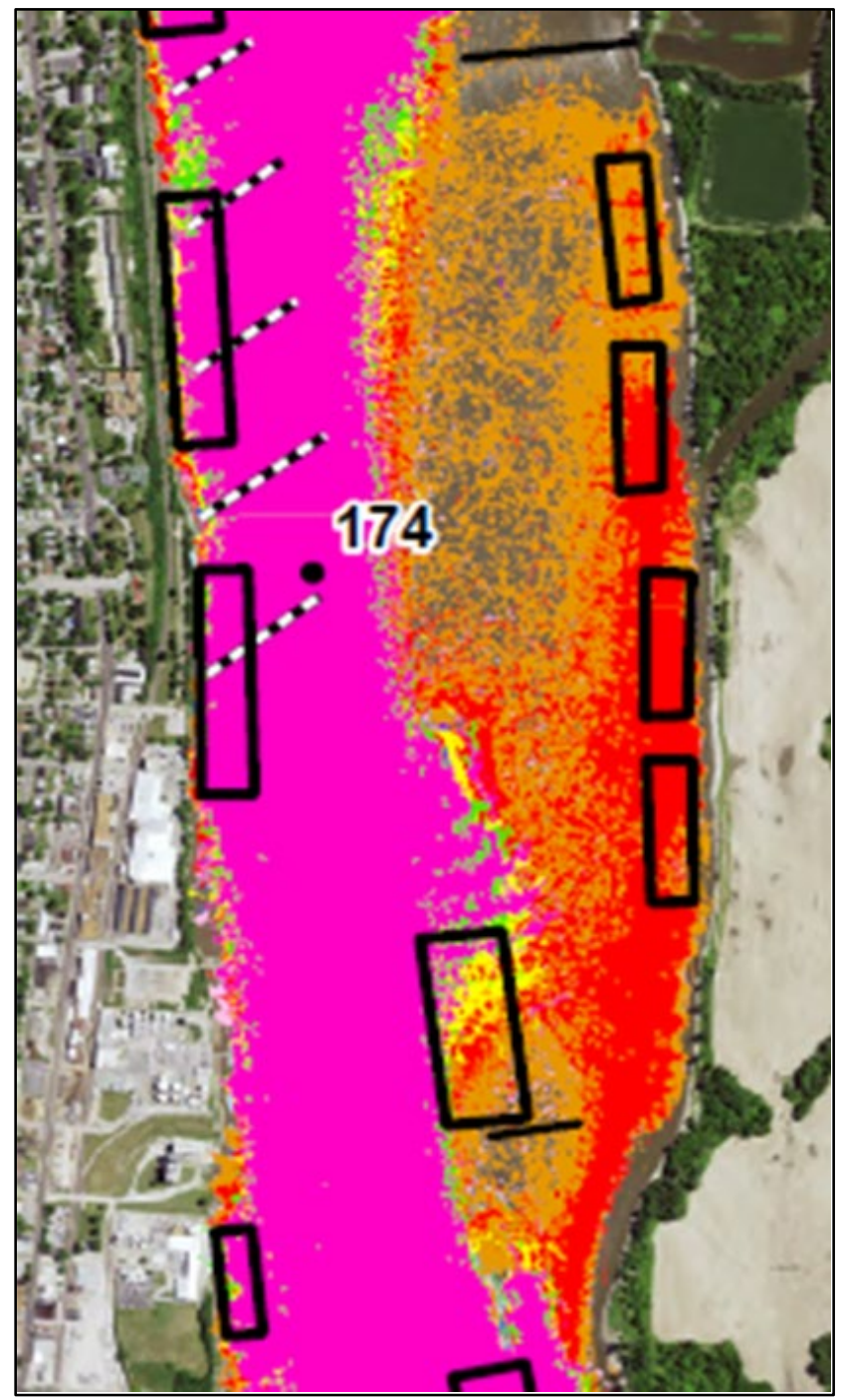

Figure 5. AIS vessel position reports (multicolor) near River Mile 174. Black boxes indicate previously known fleeting areas. Results show highly seasonal utilization of certain known fleeting areas, here shown on the left descending bank (right side of image) containing only red and orange points from 2 months of the year. Black/white lines mark weir centerlines.

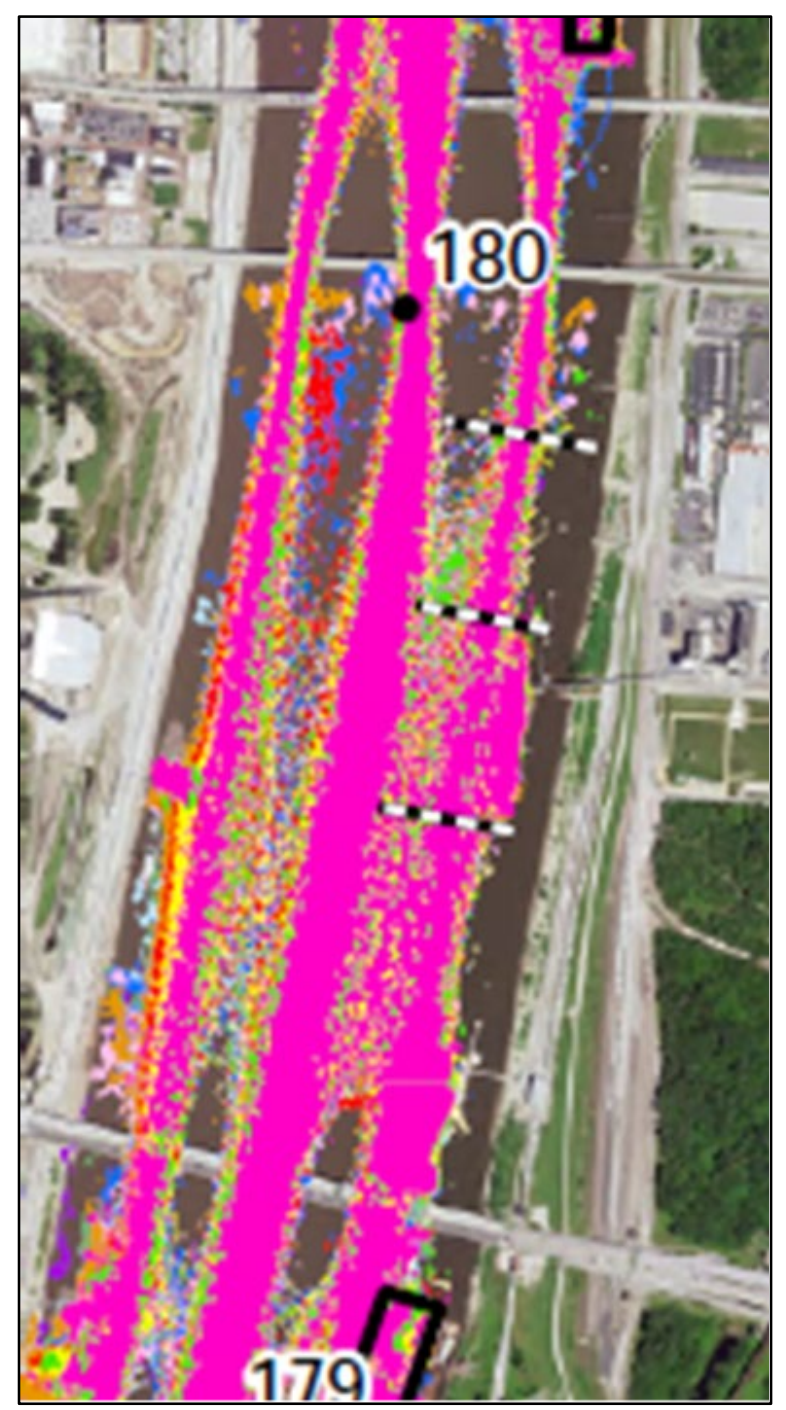

Figure 6. AIS vessel position reports (multi-color dots) near River Mile 180. Black box indicates a previously known fleeting area. Results show utilization of primary and secondary navigation channels in an area with multiple bridge spans in close proximity. Black/white lines mark weir centerlines. 
The results of this study of the MMR between River Mile 157.0 and River Mile 184.0 have informed the MVS river engineering team about commercial vessel activity that was previously unknown. A summary of the fleeting area findings is presented in Table 2.

\begin{tabular}{|l|c||}
\hline $\begin{array}{l}\text { Table 2. Fleeting activity along the MMR, between River } \\
\text { Mile 157.0 and River Mile 184.0, summary. }\end{array}$ \\
\hline \hline Commercial Vessel Fleeting Activity Metric & $\begin{array}{c}\text { Number of } \\
\text { Fleeting Boxes }\end{array}$ \\
\hline Fleeting areas with lower-than-expected activity & 15 \\
\hline Geospatially defined fleeting boxes requiring adjustment & 30 \\
\hline $\begin{array}{l}\text { Potential new loading facility boxes and fleeting boxes to } \\
\text { be created in a geospatial database based on results }\end{array}$ & 21 \\
\hline Seasonal fleeting operations identified & 6 \\
\hline Total fleeting locations identified in study area & 78 \\
\hline
\end{tabular}

By visualizing 3 years of historical AIS records, multiple areas of intense commercial activity were eliminated from further consideration for siting of river training structures. Potential conflict with shipping interests has been avoided as a result. In addition, these results have prompted a re-evaluation of the MVS geospatial fleeting data and a discussion of how to best update the MVS-maintained geospatial fleeting location records that are used across multiple mission areas.

ADDITIONAL INFORMATION: This Coastal and Hydraulics Engineering Technical Note was prepared by Marin Kress (Marin.M.Kress@usace.army.mil), US Army Engineer Research and Development Center. Portions of this work were previously described in a 2019 whitepaper released by the MVS Applied River Engineering Center for which Mr. Cory Tabbert (Cory.R.Tabbert@usace.army.mil) served as team lead. This publication is funded by the USACE Navigation Systems Research Program and should be cited as follows:

Tabbert, C., J. Vest, A. Rhoads, D. Myers, T. Lauth, E. Brauer, J. Wallace, D. Gordon, and M. Kress. 2020. AIS Data Case Study: St. Louis Area Commercial Vessel Fleeting Activity and Potential River Training Structures. ERDC/CHL CHETN-IX-52. Vicksburg, MS: US Army Engineer Research and Development Center. http://dx.doi.org/10.21079/11681/36334

\section{REFERENCES}

Dijoseph, P. K., K. N. Mitchell, B. J. Tetreault, and J. Marshall. 2019. Inland Marine Transportation System Travel Time Atlas via Automatic Identification System (AIS) Data: Ohio River, Upper Mississippi River, and Illinois River. ERDC/CHL TR-19-15. Vicksburg, MS: US Army Engineer Research and Development Center. http://chl.erdc.usace.army.mil

ESRI. 2019. ArcMap 10.4.1. [software program]. Redlands, CA.

Mitchell, K. N., and B. N. Scully. 2014. "Waterway Performance Monitoring via Automatic Identification System (AIS) Data." Transportation Research Record: Journal of Transportation. 2426(1): 20-26. https://doi.org/10.3141/2426-03 
Scully, B., and K. N. Mitchell. 2015. Archival Automatic Identification System (AIS) Data for Navigation Project Performance Evaluation. ERDC/CHL CHETN-IX-40. Vicksburg, MS: US Army Engineer Research and Development Center. http://chl.erdc.usace.army.mil/chetn

St. Louis Regional Freightway. 2019. St. Louis Regional Freightway. "The Freightway: Advantages: America's Third Largest Inland Port." St. Louis, MO. https://www.thefreightway.com/advantages/americas-third-largest-inland-port/

USACE-ERDC (US Army Corps of Engineers, US Army Engineer Research and Development Center). 2018. AIS Analysis Package (AISAP). Software package. https://ais-portal.usace.army.mil

USACE-WCSC (US Army Corps of Engineers, Waterborne Commerce Statistics Center). 2019. Waterborne Commerce Statistics Center - Data for Downloading. https://publibrary.planusace.us/\#/series/Data\%20for\%20Downloading

USCG (US Coast Guard). 2018. Navigation Center: Automatic Identification System Overview. http://www.navcen.uscg.gov/?pageName=AISmain

Young. D., and B. Scully. 2018. "Assessing Structure Sheltering via Statistical Analysis of AIS Data." J. Waterway, Port, Coastal, and Ocean Engineering 144(3): 04018002. https://doi.org/10.1061/(ASCE)WW.1943-5460.0000445

NOTE: The contents of this technical note are not to be used for advertising, publication or promotional purposes. Citation of trade names does not constitute an official 